\title{
$X$ monosomy and balanced Robertsonian translocation in a girl with Turner Syndrome
}

\author{
Aline Lourenço da Silva, Renata LL Ferreira de Lima, Lucilene Arilho Ribeiro \\ and Danilo Moretti-Ferreira \\ Universidade Estadual Paulista 'Júlio de Mesquita Filho', Serviço de Aconselhamento Genético, \\ Botucatu, SP, Brazil.
}

\begin{abstract}
We describe a case of $X$ monosomy associated with a maternally inherited $t(13 ; 14)$ Robertsonian translocation in a girl with Turner syndrome. The girl's X chromosome was demonstrated to be maternally inherited, ruling out the hypothesis that the translocation exerted an interchromosomal effect on the origin of the monosomy. Chromosomes 13 and 14 showed biparental inheritance.
\end{abstract}

Key words: Robertsonian translocation, X monosomy, interchromosomal effect.

Received: August 7, 2004; Accepted: August 15, 2005.

It has been suggested that chromosomal rearrangements may disturb meiotic disjunction of chromosomes not involved in the rearrangement, resulting in an interchromosomal effect (Hamerton et al., 1968; Subri et al., 1980). We describe a case of X monosomy associated with a maternally inherited $\mathrm{t}(13 ; 14)$ Robertsonian translocation in a girl with Turner syndrome. This study was approved by the ethics committee of our institution and informed consent was obtained from the parents of the girl.

The five-year-old female proband was referred to our clinic because of short stature and facial dysmorphism. Clinical examination revealed short stature $(<2.5$ percentile), weight between 2.5 and 10 percentile, flat frontal, large and prominent low-set ears, papebral ptosis, high nasal bridge, micrognathia, long philtrum, high palate, clinodactyly of the fifth left digit, and hypoplastic toe nails. Neuropsychological development was appropriate for the age. Chromosome analysis showed monosomy $\mathrm{X}$ and a Robertsonian balanced translocation - 44,X,der $(13 ; 14)$ (q10;q10) karyotype. The girl's mother (who had a history of miscarriage) carried a balanced translocation but her father's karyotype was normal.

To verify whether or not the Robertsonian translocation influenced non-disjunction of the X-chromosome, we determined the parental origin of the girl's $\mathrm{X}$ chromosome and normal chromosomes 13 and 14. Poly-

Send correspondence to Danilo Moretti Ferreira. Universidade Estadual Paulista 'Júlio de Mesquita Filho', Serviço de Aconselhamento Genético, Distrito de Rubião Júnior s/n, 18618-000 Botucatu, SP, Brazil. E-mail: sag@fmb.unesp.br. merase chain reaction was performed using DNA extracted from peripheral blood lymphocytes. We analyzed the $\mathrm{CAG}$ repeat on exon 1 of the $\mathrm{X}$ chromosome androgen receptor $(A R)$ gene (Bharaj et al., 1999) and polymorphic markers on chromosome 13 (D13S787 and D13S895) and 14 (D14S592, D14S608 and D14S617). Our analysis showed both maternal inheritance of the $\mathrm{X}$ chromosome (Figure 1) and biparental inheritance of chromosomes 13 and 14.

Three previous cases of monosomy $\mathrm{X}$ associated with a $\mathrm{t}(13 ; 14)$ translocation have been reported. Salamanca et al. (1985) reported a case of maternally inherited $\mathrm{t}(13 ; 14)$ translocation but did not investigate the parental origin of the X-chromosome non-disjunction. Laszlo et al. (1984) reported the case of a patient, his mother and sister, who all had a $\mathrm{t}(13 ; 14)$, but found no evidence of an interchromosomal effect. Krajinovic et al. (1994) found that both the $\mathrm{X}$ chromosome and the $\mathrm{t}(13 ; 14)$ translocation in one of their patients were paternally inherited and thus demonstrated that the translocation had no effect on X chromosome non-disjunction.

Kondo et al. (1979) compared the expected and observed frequency of the 45, X karyotype combined with unrelated balanced translocations and concluded that there was no causal relationship between the two chromosomal abnormalities

In our patient both the translocation and the $\mathrm{X}$ chromosome were demonstrated to be maternally inherited, ruling out a meiotic non-disjunction interchromosomal effect. 

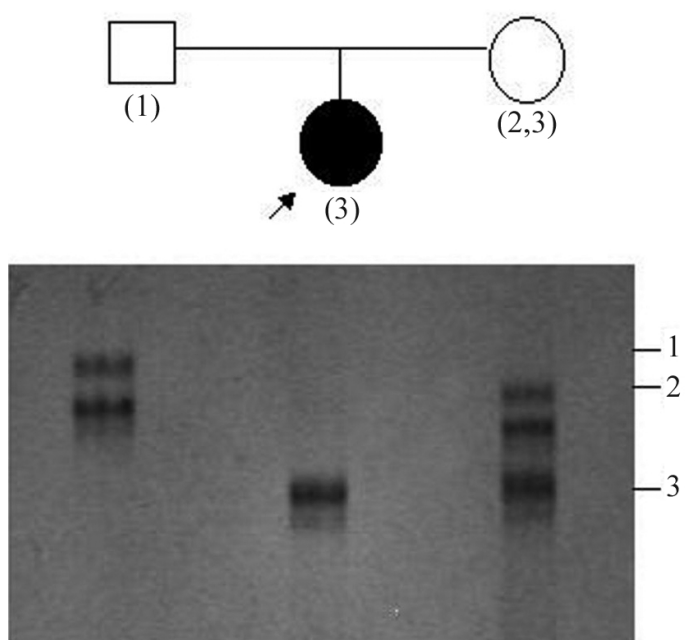

Figure 1 - The androgen receptor $(A R)$ gene CAG repeats of a 45,X girl (arrow) and her parents were genotyped by PCR and electrophoresis using $6 \%$ denaturing polyacrylamide gel. The allele on the girl's X chromosome was inherited from her mother.

\section{Acknowledgment}

We thank Dr. Silvia Regina Rogatto, Dr. Claúdia Ap. Rainho and Fabíola Encinas Rosa for help in the analysis. This work was supported by Fundação Lucentis.

\section{References}

Bharaj BS, Vassilikos EJ and Diamandis EP (1999) Rapid and accurate determination of $(\mathrm{CAG})_{\mathrm{n}}$ repeats in the androgen receptor gene using polymerase chain reaction and automated fragment analysis. Clin Biochem 32:327-332.

Hamerton JL, Gianelli F and Carter CO (1968) A family showing translocation of a $\mathrm{D} / \mathrm{D}$ reciprocal translocation and a case of regular 21 trisomy Dow's syndrome. Cytogenetics 2:194-207.

Gianaroli L, Magli MC, Ferraretti AP, Munne'S, Balicchia B, Escudero T and Crippa A (2002) Possible interchromosomal effect in embryos generated by gametes from translocation carriers. Human Reproduction 17:3201-3207.

Krajinovic M, Ivanovic K, Mestroni L, Diklic V and Nikolis J (1994) Parental origin of the $X$ chromosome in a patient with a robertsonian translocation na Turner's syndrome. J Med Genet 31:255-256.

Kondo I, Hamaguchi II, Matsura A, Nakajima H, Koyama A and Tukica H (1979) A case of Turner's syndrome with familial balanced translocation $\mathrm{t}(1 ; 2)(\mathrm{q} 32 ; \mathrm{q} 21)$ mat. J Med Genet 16:321-323.

Laszlo J, Bosce P, Gaal M and Toth A (1984) A case of 44,X streak gonad syndrome combined with familial balanced 13/14 translocation. Acta Med Hung 41:223-227.

Salamanca F, Buentello L, Sanchez J and Armendares S (1985) A patient with 44 chromosomes. Ann Genet 28:130-132.

Subri I (1980) Reciprocal translocation with a special reference to reproductive failure. Hum Genet 55:303-307.

Associate Editor: Angela M. Vianna-Morgante 